Reflexes.

The deep reflexes are often affected by Intrinsic cerebellar lesions in such a mixed way as to produce a plcture almost characteristic in its irregularity, but very difficult to generallze. We may gay in a broad way that any reflex may be exaggerated or reduced, and both changes may occur with different retiezes at the same time or with the game reflez at different times; and that; therelore, the localizing value of auch changes is often slight as regards the side of the cerebellum involved. For example, the knee jerk on the side of the lesion is often exaggerated, but it may equally well be reduced. It is possible, however, to be more definite as to the absence as $\mathrm{a}$ sign of intrinslc cerebellar disease, of the Bablnskl toe phenomenon and its variants, the "fan algn," Schäfer's, Oppenheim's, and Remak's reflif xes.

I may now shortly relate to you the symptoms and signs of a second case, as they show very well how some of the features we have been describlng may be comblned in an actual example.

\section{Cask II.}

E. G., a married woman of 29, was admitted September 5th, 1907. She had been ill for six weeks, but no very defnite soconnt of the illness conld be obtained. She had had a discharge from the left $\mathrm{far}$ eince the beginning of the lliness. charge from the left ear since the beginning of the lllness.
For the last three weeks she had had much headache, and had For the last three weeks ehe had had much headache, and had
taken to her bed. At the beginning of this period she had had much shivering. At the time of admission a large subcataneous absoess was pregent bebind the ear. Thls was Immediately Incised. Some hours later systematio examination gave the following results : The patient was decidedly letharglo, and spoko with a blnrred articulation. she angwored questlons intelligently, and understood all that was said to her. The tempersture was normal, and the pulse 90

Ocular Signs. - Conjugte movements to the left were dis Ocular Signs.-Conjugate movements to the left were dis-
tlnctly wesk, those to the right norms. The left eye did not move to the left as well as to the right, co that there was probably some special weakness of the left $\in$ xternal rectus. There was no deviation of the optic axes when the eyes were at rest, but the left eye moved upward more readily ihan the right, and downward less readily. Nistagmus was present during all movements excent downwards, and was most marked when the patlent looked to the left. There was no optic nearitis.

Reflexes.-I - Ieft knee and Achilles jerks exeggerated on the left side. Plantar reflexes very feeble, and showing slight flexion. Other reflexes normal.

Motor. -There was a very little weakness of the left arm and leg, so slight, indeed, as probsbly to be without significance. Movements of left arm showed distinct ataxy, movements of right normal. Marked dysdiadokokinesis was present on the left side. Flexion of elbow against resistanice with sudden release showed, on the left slde only, a marked continuation of the movement.

It was, of course, obvious at once that a lesion of the cerebellum was present, and operation was carried out. A large extradural abscess wes fourd in the rosterior foses, supparatlon in the lateral sinus, and a large abscess in the left lobs of the cerebellum. These were drsined, and the patient did well for ten days, when she began to develop gens ral eupparative meningltis.

The case shows well how the general and cerebral symptoms may be latent, and yet the intrinsic cerebellar algns be definite enough to establish the dagnosis with certalnty. It also affords an interesting contrast with Case I in the distribution of the signs. In both the ocular gigns were well marked, and in nelther was there optic neuritis. But whereas in the first case the motor signs in the limbs were those of paresis alone, in the second case the motor slgns were those of inco-ordination alone.

I ahall make no attempt to deal with the treatment of cerebellar abscess, but confine myeelf to a short remark on each of two points in connexion therewlth. In the first place, it seems even yet not to be fully recognized how extremely urgent is the need for prompt operation in all cases of cerebellar abscess. In fact, in any case of increasing intracranial tenslon in the posterior fossa, so great is the risk of sudden death from respiratory fallure, that as soon as the diagnosis is made the case should be looked upon as quite as urgent as one of perforated gastric ulcer or of rupture of the spleen. This danger bears no relation whatever to the severity or mildness of the symptoms and slgns.

As regards actual operative technlque, the only polnt I wish to draw your attention to is that the chance of fallIng to find a small and deep.seated cerebellar abscess is considerable, and that in such a case unquestlonabls the best course to pursue is to remove a considerable ares of bone and Incise the dura freely, so that if an abscess is actually present it can extend more freely towards the surface than elsewhere, and the appalling danger of sudden pressure on the medulla thus be minlmized.

\section{THE COLONY AND BROMIDE TREATMENT}

\section{OF EPILEPSY.}

By A. J. McCALLUM, M.B., F.R.C.8.E., PHYSICIAN TO STARNTHWATTE COLONY, WRSTMORLAND.

Dorivg the past three and a half years I have had charge of C.U.S.8. Colony and Epileptic School for boys at Starnthwaite, and the results obtained from what I might call the radical ase of bromide are, I think, worth pub. lishing.

The treatment is based on the assumption that early epilepsy is far more frequently the direct result of peripheral Irritation than of Gowers's " abnormal state of chemical nutrition, whereby the molecules are more easily detached and their atoms yield with undue facility to the attraction of the adjacent orygen," and that the liberal use of bromide prevents this peripheral reflex from distarbing the cerebral harmony and saves the brain from contracting the bad habit of epilepsy on the slightest sensory disturbances. The dose of bromide given is that amount which is necessary to control the fits. This is done in some cases by 40 grains a day; oftener 100 grains is required, and as much as 300 grains has been necessary.

During 1903 we treated four boys - two of them we have discharged as having their epilepsy arrested, though atill under observation. One has been removed by his father as cured. He has had no fits and no bromide for a year. The other boy was considered at first nnsuitable for treatment, but was put on bromide in March of this year, and has had his fits reduced from ten a month to one in eight monthe.

\begin{tabular}{|c|c|c|c|c|c|}
\hline & $\begin{array}{l}\text { Fita in } \\
1903 .\end{array}$ & $\begin{array}{c}\text { Fjts in } \\
1504 .\end{array}$ & $\begin{array}{c}\text { Fits in } \\
1965 .\end{array}$ & $\begin{array}{c}\text { Fita in } \\
\text { 1506. }\end{array}$ & \\
\hline W. C. L. .. & 84 & 11 & 1 & 0 & Removed by father. \\
\hline A. M. .. & 267 & 0 & 2 & 0 & Working on farm. \\
\hline A. B. & 25 & 0 & 1 & 1 & Working on farm. \\
\hline E. T. & 32 & i2 & 99 & 27 & \\
\hline
\end{tabular}

The case of E. T. shows average fits for 1903 to be 32 . Daring 1904 he had no trcatment and the fits numbered 72; in 1905 he had 99 fits without treatment, but during 1906 he was treated and hls fits were reduced to 27, and of these only 4 occurred during the time he was taking bromide. The bromide was not started until March 27th.

of the 10 cases admitted during 1904, 6 were placed on bromide with the followine resul ts :

\begin{tabular}{lll|c|c|c|l}
\hline & & $\begin{array}{c}\text { Fits in } \\
1904 .\end{array}$ & $\begin{array}{c}\text { Fitg in } \\
\text { Ii0j. }\end{array}$ & $\begin{array}{c}\text { Fits in } \\
1906 .\end{array}$ & \\
\hline H. V. &.. &.. & 197 & 3 & 4 & 3till in school. \\
F. S. & $\ldots$ &.. & $\varepsilon 0$ & 5 & 3 & Still in school. \\
A. Y. & $\ldots$ &.. & 130 & 1 & 0 & Working on farm. \\
R. B. & $\ldots$ &.. & 238 & 0 & 0 & Working on farm. \\
F. W. & $\ldots$ &.. & 47 & 11 & 0 & Working on farm. \\
F. B. &.. &.. & 72 & 16 & 27 & st school. \\
\hline
\end{tabular}

Two were discharged as mental cases and 2 considered unsultable for treatment.

Mr. Colyer, our Superintendent at Starnthwaite, keeps most ascurate daily, monthly and yearly records of the dose of bromide given, and the number of fits that occur in each day, month, and year. I give here a few cases from his year-book. The first is most instructive in several polnts. I did not consider the case a very suitable one for bromlde, and although he was put on it for a few months it was stopped. Why, I am not quilte clear. Bromide was resumed in March, 1906, and his case now affords us three periods-1903-4 partial bromide, 1905 no bromide, 1906 with bromlde. The records of the other cases explain themgelves. 
CASE F. T.

\begin{tabular}{|c|c|c|c|c|c|c|c|c|c|c|c|c|c|c|c|c|c|c|c|c|c|c|c|c|c|}
\hline \multirow{2}{*}{ Year. } & \multicolumn{2}{|c|}{ Jan. } & \multicolumn{2}{|c|}{ Feb. } & \multicolumn{2}{|c|}{ March. } & \multicolumn{2}{|c|}{ A pril. } & \multicolumn{2}{|c|}{ May. } & \multicolumn{2}{|c|}{ June. } & \multicolumn{2}{|c|}{ July. } & \multicolumn{2}{|c|}{ August. } & \multicolumn{2}{|c|}{ Bept. } & \multicolumn{2}{|c|}{ Oct. } & \multicolumn{2}{|c|}{ Nov. } & \multicolumn{2}{|c|}{ Dec. } & \multirow{2}{*}{$\begin{array}{l}\text { Total Fits } \\
\text { for Year. }\end{array}$} \\
\hline & Br. & Fits. & Br. & Fits. & $\mathrm{Br}$. & Fits. & Br. & Fits. & Br. & Fits. & Br. & Fits. & Br. & Fits. & Br. & rits. & Br. & Fits. & Br. & Fits. & Br: & Fits. & Br. & rits. & \\
\hline 1903 & -1 & - & - & - & - & - & - & - & - & - & - & 2 & - & 5 & - & 4 & - & 4 & - & 1 & - & 0 & - & 0 & 16 \\
\hline 1504 & - & 0 & - & 4 & - & 5 & - & 4 & - & 5 & - & 4 & - & 19 & - & 5 & - & 0 & - & 4 & - & 17 & - & 5 & 72 \\
\hline $19 \times 5$ & - & 2 & - & 13 & - & 3 & - & 5 & - & 10 & - & 9 & - & 6 & - & 5 & - & 10 & - & 10 & - & 10 & - & 16 & 99 \\
\hline 1906 & - & 14 & - & 9 & 20 & 3 & 40 & 0 & 40 & 0 & 40 & 0 & 40 & 0 & 40 & 0 & 40 & 1 & 40 & 0 & 40 & 0 & 40 & 0 & $\begin{array}{c}\text { gince Br. } \\
\text { started } \\
4\end{array}$ \\
\hline 1907 & 40 & 0 & 40 & 0 & 40 & 0 & 40 & 0 & 40 & 0 & 40 & 0 & 40 & 0 & 40 & 0 & 30 & 0 & 20 & 0 & 30 & 0 & 20 & 0 & 0 \\
\hline
\end{tabular}

Cast A. M.

\begin{tabular}{|c|c|c|c|c|c|c|c|c|c|c|c|c|c|c|c|c|c|c|c|c|c|c|c|c|c|}
\hline \multirow{2}{*}{ Year. } & \multicolumn{2}{|c|}{ Jan. } & \multicolumn{2}{|c|}{ Feb. } & \multicolumn{2}{|c|}{ March. } & \multicolumn{2}{|c|}{ April. } & \multicolumn{2}{|c|}{ Мау. } & \multicolumn{2}{|c|}{ June. } & \multicolumn{2}{|c|}{ July. } & \multicolumn{2}{|c|}{ August. } & \multicolumn{2}{|c|}{ Sept. } & \multicolumn{2}{|c|}{ Cct. } & \multicolumn{2}{|c|}{ Nov. } & \multicolumn{2}{|c|}{ Dec. } & \multirow{2}{*}{$\begin{array}{l}\text { Total Fits } \\
\text { for Year. }\end{array}$} \\
\hline & $\mathrm{Br}$. & Fits. & Br. & Fits. & $\mathrm{Br}$. & Fits. & Br. & Fits. & Br. & Fits. & Br. & Fits. & Br. & Fits. & $\mathrm{Br}$ & Fits. & $\mathrm{Br}$ & Fits. & $\mathrm{Br}$ & Fits. & $\mathrm{Br}$ & Fits. & Br. & Fits. & \\
\hline 1904 & $\underset{*}{G r}$. & 4 & $\mathrm{Gr}$. & 31 & Gr. & 33 & Gr. & 36 & Gr. & 47 & Gr. & 29 & ir. & 55 & $\underset{i 0}{\mathrm{Gr}}$ & 9 & $\begin{array}{c}\mathrm{Gr} . \\
50\end{array}$ & 21 & $\underset{\text { Gr. }}{\text { Gr. }}$ & 0 & $\underset{t 0}{G r}$ & 10 & $\begin{array}{c}\text { fr. } \\
\mathbf{t} 0\end{array}$ & 2 & 277 \\
\hline 1905 & 60 & 0 & 60 & 0 & 60 & 0 & 60 & 0 & 60 & 0 & 60 & 0 & EO & 0 & 60 & 1 & 60 & 0 & 60 & 0 & 60 & 1 & 60 & 0 & 2 \\
\hline 1906 & 60 & 0 & 60 & 0 & 60 & 0 & 60 & 0 & $\epsilon 0$ & 0 & 60 & 0 & 60 & 0 & $\epsilon 0$ & 0 & 60 & 0 & 60 & 0 & EO & - & - & - & 0 \\
\hline
\end{tabular}

CASE H. V.

\begin{tabular}{|c|c|c|c|c|c|c|c|c|c|c|c|c|c|c|c|c|c|c|c|c|c|c|c|c|c|}
\hline \multirow{2}{*}{ Year. } & \multicolumn{2}{|c|}{ Jan. } & \multicolumn{2}{|c|}{ Feb. } & \multicolumn{2}{|c|}{ March. } & \multicolumn{2}{|c|}{ April. } & \multicolumn{2}{|c|}{ May. } & \multicolumn{2}{|c|}{ June. } & \multicolumn{2}{|c|}{ Jujy. } & \multicolumn{2}{|c|}{ sugust. } & \multicolumn{2}{|c|}{ Sept. } & \multicolumn{2}{|c|}{ Oct. } & \multicolumn{2}{|c|}{ Nov. } & \multicolumn{2}{|c|}{ Dec. } & \multirow{2}{*}{$\begin{array}{l}\text { Total Fits } \\
\text { for Year. }\end{array}$} \\
\hline & $\mathrm{Br}$ & Fits. & $\mathrm{Br}$ & Fits. & $\mathrm{Br}$ & Fits. & $\mathbf{B r}$ & Fits. & $\mathrm{Br}$ & Fits & Br. & Fits. & $\mathrm{Br}$ & Fits. & $\mathrm{Br}$. & Fits. & $\mathrm{Br}$ & Fits. & $\mathrm{Br}$ & Fits. & $\mathrm{Br}$ & Fits. & $\mathrm{Br}$ & Fits. & \\
\hline 1904 & - & - & - & - & - & - & - & - & - & 44 & - & 24 & $\begin{array}{l}\text { Gr. } \\
\vdots 0\end{array}$ & 44 & $\begin{array}{l}\mathrm{Gr} \\
\mathrm{Z} 0\end{array}$ & 18 & $\begin{array}{c}G \mathbf{r} \\
20\end{array}$ & 8 & $\begin{array}{l}G r . \\
40\end{array}$ & 1 & $\begin{array}{l}\mathbf{G r} \\
40\end{array}$ & 0 & $\begin{array}{l}G \mathbf{G r} \\
50\end{array}$ & 1 & 133 \\
\hline 1905 & 50 & 0 & $€ 0$ & 1 & 60 & 0 & $60^{\prime}$ & 1 & E0 & 0 & 70 & 1 & 80 & 0 & $\varepsilon 0$ & 0 & i0 & 0 & EO & 0 & 60 & 0 & EO & 0 & \\
\hline 1906 & 60 & 0 & 60 & 1 & 60 & 0 & 60 & 0 & $\epsilon 0$ & 0 & 70 & 2 & 70 & 0 & 70 & 0 & $i 0$ & 0 & 70 & 0 & - & - & - & - & 8 \\
\hline
\end{tabular}

Case B. B.

\begin{tabular}{|c|c|c|c|c|c|c|c|c|c|c|c|c|c|c|c|c|c|c|c|c|c|c|c|c|c|}
\hline \multirow{2}{*}{ Year. } & \multicolumn{2}{|c|}{ Jan. } & \multicolumn{2}{|c|}{ Feb. } & \multicolumn{2}{|c|}{ March. } & \multicolumn{2}{|c|}{ April. } & \multicolumn{2}{|c|}{ May. } & \multicolumn{2}{|c|}{ June. } & \multicolumn{2}{|c|}{ JuJy. } & \multicolumn{2}{|c|}{ A ugust. } & \multicolumn{2}{|c|}{ Sert. } & \multicolumn{2}{|c|}{ Oct. } & \multicolumn{2}{|c|}{ Nov. } & \multicolumn{2}{|c|}{ Dec. } & \multirow{2}{*}{$\begin{array}{l}\text { Total Fits } \\
\text { for Year. }\end{array}$} \\
\hline & $\mathrm{Br}$ & Fits & Br. & Fits. & $\mathrm{Br}$ & Fits. & $\mathrm{Br}$. & Fits. & $\mathrm{Br}$. & Fits. & Br. & Fits. & $\mathrm{Br}$ & Fits. & Br. & Fits. & $\mathbf{B r}$ & Fits. & $\mathrm{Br}$. & Fits. & Br. & Fits. & Br. & Fits & \\
\hline 1907 & - & - & - & - & - & - & - & - & - & - & - & 18 & - & 71 & $\varepsilon 0$ & 15 & 40 & 8 & 60 & 3 & 60 & 1 & 60 & 3 & 119 \\
\hline 1905 & 70 & 0 & 70 & 0 & 70 & 0 & i0 & 0 & $: 0$ & 0 & 70 & 0 & :0 & 0 & 70 & 0 & 60 & 0 & 50 & 0 & 50 & 0 & 50 & 0 & $\mathbf{0}$ \\
\hline 1906 & 40 & 0 & 40 & 0 & 40 & 0 & 40 & o & 40 & 0 & 40 & 0 & 40 & 0 & 40 & 0 & 40 & 0 & 40 & 0 & - & - & - & - & 0 \\
\hline
\end{tabular}

Is the condition we recognize as epllepsy a disease or Is it only symptomatic? Is there such a malady as idiopathic epllepsy? Epilepsy must be regarded as the result of a disease or the perpetuated sequel of one, $a$ viclous habit of brain being established. The only point on which there seems to be unanlmity of opinion is that one fit predisposes to another, the oftener they occur the oftener they are likely to occur, until they become in a way self-perpetuating. Much has been written as to the relative importance of predisposing and exciting causes. For practical purposes it would be well to ignore predlsposing caugeg, and, atter all, their presence is a supposition. It is supposed that convalsions would not occur during teething unless there was a predisposing cause such as heredity, rickets, or nutritlonal Instabillty. Yet In my cases rickets and heredity have been consplcuously absent. I can trace 33 per cent. of my cases to their origin during teething, and one of these cut teeth so early as the third month, and in others of which I have had personal knowledge teething was by no means delayed. Moreover, one has to think of the hundreds of eminently rickety chlldren who never have a fit. In my experience the only constant factor in infantlle convulsions has been the evidence of pain and unrest, and the number of cases of infantile convulslons that have gone on to epilepsy has been large.

Pain and nerve tension seem to so disturb cerebral harmony that there is a furious outburst of energy glving rise to a display of sensory, vasomotor, and motor function constltuting the fit. The fit is so obviously an outcome of cortex function that idiopathlc epilepsy is regarded as a disease of that arfa, Epilepey is a malady that lasts for many years, it is a malady that is very prevalent, it has afforded the fullest and best opportunity of exhlblting its pathology. Thousands of po: have been made by the best pathologists on cases that ought to have demonstrated the lesions in its completed ought to Yave no single constant unvarying condition has been found. Pigmentations and vacuolation cells, changes in the perivascular epaces, Induration of the pes hippocampl have been given up as the causes of epllepsy; degeneration of the cells in the second cortlcal layer has degeneration of the tendency now is to assume that an unseen and invisible lesion is present, a chemlcal one -one adduced by Gowers and accepted generally because Gowers has said it, and that is, "an abnormal state of chemical nutrition, whereby the molecules are more easily detached and their atoms yleld with undue facllity to the attraction of the adjacent oxygen." If this is the cange of epllepsy it is not surprising that path. ologists have been unable to see it. Briefly, the reasoning seems to be that epllepsy is, from a study of Its symptoms -aurs, loss of consciousness, tonic and clonic spasm, convulsions, coma, drowsiness and sleep-so obviously a 
display of the functions of the cerebral cortex, that the disease must be seated there, and this is supported by experlmental investigations, especlally those of Bechterew. He proved that convulsions with tonlc and clonlc spasm followed by coma just like epllepsy are produced on electrical stimulation of the brain cortex. But does it follow that the disease must be in the cortex becanse the eymptoms are those of cortical function and they have been produced by stimulation of the cortex? I think not; Bechterew's experiment amounts to this, that a healthy braln gave eplleptic symptoms on stimulation. This is significant; there are two factors-healthy brain and stfmulation-and they give epilepsy. No need of heredity, no need of rickets, no need of abnormal chemical nutrition, with detaching molecules and yielding atoms. I am of opinion that we have in Bechterew's experiment the explanation of epllepsy as we find it in everyday practice -a healthy brain bursting out into fury owing to its over-stimalation by sensory impressions poured Into it from one or more or varying sensory areas, the pain and tension of teething acting like the electrical stimnlation: the brain gets teased, less tolerant, almost viclous in its hablts, so that it will reply, long after teething has passed away, to other sensory distarbances with an epileptlc fit, thus explaining how 80 many cases of infantlle convulgion go on to what is called idlopathic epilepsy. Epilepsy thus becomes a reflex act in its origin and a cerebral vice in its faller development and perpetuation.

Thls view of epllepsy in its orlgin being mainly, 11 not wholly, a reflex disease, brings into harmony many apparently hopelessly divergent facts regarding its etiology and treatment; for there are undoubted cases on record where correction of errors of refraction has cured the epilepsy, and of epilepsy ceasing after the nose and throst have been cleared of adenoids. I. have had a case where constipation was the cause and cascara the cure. Osler mentions a case where an undescended testis was the cause of epllepsy; pressure on it produced an attack; its removal cured the disease. Gynaecologists have seen the origin of epllepsy in ovarian irritations. Oculists have found it in eye-strain. ' Dletetlc specialists have traced it to the Sunday dinner, while the genito-urinary surgeon accounts for it all by a floating kidney. They are each and all right in their observation if they would only allow that causes might be found outside their area requlring treatment outside their routine.

\section{TRHATMHAT.}

Treatment of epllepsy is to remove the canse where this can be done, and, where it cannot, render it inoperative. The need of classification is again obvious; there are some cases that must be ruled outslde the hope of much betterment by any treatment-developmental cases, cases arlsing in imbeclles, in the microcephalle, in inoperable tamour cases, and probably the confirmed eplleptie, the Indivldual. who has had severe epllopse for twenty or thirty years, and whose mind, brain, and body are hopelessly wrecked by repeated fits. His time for treatment is past. Peripheral, traumatic, emotional, and toxic causes give rise to about 60 or 70 per cent. of all cases in chlldhood and youth, and are, in my opinion, curable if treated early and long enough.

Bromide treatment is necessary and curative in peripheral, tranmatic, emotional, and toxic cases. I think it was Sir T. R. Fraser who first demonstrated that the action of bromide was one of allaying reflex action. A stimulus of given strength was applied to the leg of a frog, general muscular contractions followed; under bromide the same stimulus produced less contraction, while more bromide limited the contraction to the side of the body that was atimulated. A larger dose of bromide limited the contraction to the leg only.

Epllepsy being due to severe, prolonged, or repeated sensory stimulation of brain, I use that amount of bromide that is necessary to stop the sensory stimulation. The amount requlred to do this varles exceedingly. Eighty grains a day is the average, but so small a dose as 60 grains has been sufficlent to arrest epllepsy of an intengity that was to be estimated by the occurrence of 267 "grand mal" selzures a year. Among the boys at the colony now, 130 grains a day has been the highest dose given so far; but I have given 320 in private practice and arrested the disease. The method is to give 20 gralns night and morning, and increase by 10 grains per day as often as fits recur. Eplleptlc boys stand bromide very well; 80 or 100 grains per day are taken without them showlng any aign that they are taking a drug; 150 or 200 grains per day begins to interfere with the equilibrium - their walking becomes nncertaln, and they ought to be kept in bed. With larger doses, swallowing and organic reflezes are interfered with. Adults do not stand bromide nearly 80 well. The boy that had 320 grains had sordes on his lips and gums, his breath was foul, swallowing was difficult, there was sllght haematemesls and melaena, resplratlon was shallow, and râles were heard. The fits, which were numbering elght and ten a day, stopped, the bromide was gradually reduced, and the boy had no more fits for two years. I detected no toxic action on the heart; it remained regular throughout, no dilatation, little loss of clearness about the sounds. The toxic action of potassium salts on the heart to me seems a myth. I use citrate of potash in large doses-60 to 90 -gralng per-day-for-long periods for gravel, migralne, and some eczemas, and fall to find the slightest evidence or hear patients (olten old) complain of any symptom of heart weakness. On the other hand, with bromide I find respiration does get embarrassed, slow, shallow, or at times halting and deep, and accompanied with râles and rhonchl. I find in Martindale's Extra Pharmacopoeia, 1906, Dixon is quoted as follows: "Potassium salts adminlstered per os are non-toxic; they are excreted faster than they are absorbed."

Bromlde ragh may well be ignored. I use the best Fnglish-made bromlde, and rashes have never given me any trouble. Of 40 cases taking bromide now, only 3 show any rash; In 2 it is very faint, a few papules on the forehead. In 1 it is severe - takes the form of bolls, forming ulcers with purpuric-looking surrounding skin. This particular-boy had an attack of the same thing about a year ago, and it disappeared in three weeks without the bromide being knocked off, and without anything in the way of treatment except a soothing antlseptlc olntment. Other objections to bromlde are that it makes them look blue and blotched, and miserable, starved, dazed, and ugly. Thls is a gross libel; such appearances are not due to bromide. I had an eplleptic under my observation, bat not under my treatment, who very well lllustrated this description, but he never took bromide. He died a sulcide, and the coroner's jury returned a verdlct of death due to temporary insanity arlsing from business worrles.

For those few cases that may have their origin in absorption of toxlc products from over-eating, from unsultable food, or from constipation, diet is of Importance, but for the bulk of cases diet might be summed up in-three meals a day, everything fresh, everything limited, flesh never oftener than once a day and three times a week is ample. In the salt-free or purin-tree diet I see no likelihood of good being done.

A few more years of Starnthwaite experlence will prove whether epllepsy in the young, when taken carly and treated assiduously, can be permanently arrested. The outlook at present is very hopefal, and, if we succeed, then the question becomes a very large one, and one, I think, for the State to deal with.

\section{A CASE OF HYSTERICAL SOMNAMBULISM, SHOWING ABNORMAL ACUITY OF VISION \\ IN THE SOMNAMBULISTIC STATE.}

By JAS. W. RUSSELL, M.A., M.D.CANTAB., F.R.C.P.LOND, ASSISTANT PHYSICIAN TO THE BIRMINGHAM GENERAL HOSPITAL.

A GrRL, aged 21, a tescher, typewriter, and now a student of music, was sent to me on July 29!h, 1907, complaining of sleep-walking of a month's duration. Having at that time temporary charge of beds in the Blrmingham General Hospital, with the consent of her doctor I took her in for the sake of observation, and it was durlng her stay in that instltution that the events recorded below took place.

Family History.

The patlent's mother died aged 29, but the cause al death was not known. Her father, at the age of 26 , committed sulclde by shooting himself in her presence. Two brothers are living; one is in good health, the other 